\title{
The effect of human skills of preschool directors on trainers taking part in educational issues
}

\author{
Hasan ali Bakhtiyar Nasr Abadi ${ }^{1}$ Mohammad Mohammadi Sadr ${ }^{2}$ Kamal \\ Nosrati Heshi ${ }^{3}$ Mohammad hossein nadi ${ }^{4}$ Javad vaysi $^{5}$ \\ ${ }^{1}$ Associate Professor of Educational Sciences Department, Isfahan University. Iran \\ ${ }^{2}$ PhD student in Educational Administration, Isfahan University. Iran \\ ${ }^{3},{ }^{4,5}$ MA Student of History and Philosophy of Education, Isfahan University. Iran
}

\begin{abstract}
This study aims to investigate the effect of human skills of preschool directors on the level of trainers' participation in taking educational measures and decisions in preschool centers of Isfahan. The population is all preschool centers of Isfahan's Education Department. Two educational districts from among six educational districts of Isfahan city were randomly selected; from which 300 trainers were selected as the study sample. Researcher-made questionnaires were used to measure human skills of directors and the level of trainers' participation, the content validity of which were proved by Isfahan University experts and the reliability of the questionnaire measuring human skills of directors was calculated as 0.90 through Cronbach's Alpha and the reliability of the questionnaire measuring the level of trainers' participation was calculated as 0.88 through Cronbach's Alpha.

The following result obtained for this study using the data collected through two questionnaires and also data analysis in two levels of descriptive and inferential statistics. 1. Most directors in preschool centers (kindergartens and day care centers) have moderate human skills on directors' skills. From 300 trainers in relation to directors' skills in human skill component, 30.9\% individuals were below the average, 35\% individuals were at the average, and $34.1 \%$ individuals were above the average. There was a meaningful relation between human skills of directors and with any of the components of trainers' participation. There was also a correlation (0.78) between human skills of directors and with any of the components of trainers' participation.
\end{abstract}

Keywords: management, educational management, skill, human skill, participation, decision making, participation in decision making.

\section{Introduction}

Industrial development, scientific and technological advancement and the growth urbanization have led to fundamental changes in social institutions and cultural habits of countries. There has been an increase in material welfare of these communities, and more actions are done to provide public welfare. Education has had a key role in this procedure. (Bazelahi, 2003:6). As, now educational system in most countries is considered as of the large and complex organizations that its largeness depends totally on the extent of cultural, social, economical and technical advancement. The more advanced a society is, the more important, complex and difficult is the role of formal education in that society, and the more extensive and diverse are its organizations and the greater will be the number of its staff and students (Alagheh band, 2006:10).

Management and leadership are the foundations of every organization and community. Educational Management, among other types of managements has a special position. If the educational system of any community is at the top of all issues, Educational Management, with the same logic, will also have an important role in the improvement and development of the society. If managers of a community have enough knowledge and skills, indubitably the educational system will be very effective and highly efficient. So we can say that educational managers are responsible for the quality of the implementation of educational programs and achieving education the goals and in order to play this role they need to have the knowledge, skills, capabilities, attributes and competencies appropriate to this critical responsibility, and it is evident that managers with such important, complex and diverse tasks, must have the characteristics to help them in their serious tasks. In fact, the continuous improvement and providing the need of the society and people is in accordance with the goals of higher education (Mirkamaly, 2006:9-17).

There are different views on management skills. In one view, managers' skills are classified into identifying, adaptation and communicating skills (Hersey and Blanchard, 1995), and in another classification, managers' skills are divided into the following skills: 1. Empowerment, 2. Inspiration and experience, 3.personal cognition, 4. Viewpoint, 5. Compatibility of values (Zomorodian, 2008) and in another viewpoint, 
managers' skills are divided into decision making, establishing personal relations, and goal setting (Parkinson, et al. 1992), but management skills and the structure of skills of an organized manager were scientifically proposed by Robert. L. Katz for the first time which were published in an article in Harvard Business Review in 1955. In this article he divided the required skills of successful managers into three categories of technical, humanistic and perceptual (Katz, 2001).

Also, scientists after Katz mentioned other skills for management; Kantz has mentioned planning skill, Griffin has pointed the recognition and analysis, Kayson and Ivanovich have mentioned computer skill, and Part Velo has mentioned political skill (Fardi Azar, 2002). From among these models, the three skills of technical, humanistic and perceptual has gained more acceptability and applicability in Iran so that all management books has mentioned these as essential for all managers.

Indubitably human resources play a major role in the existence and survival of organizations. One of the most important goals of any organization is to improve its productivity and regarding the fact that humans play a vital role in creating productivity, their demands places a key impact on the organization (Ostadzadeh, 2009). And official leaders of institutions must have deep faith in the personality of each individual in the institute and sincerely want to nurture the potential talents of each person. Such a faith will create an environment in which everybody is nurtured and developed (Tousi, 2006: 105).

An important part of the leaders' time and work is spent on problem solving and decision making. Decision making process encompasses three areas that include individuals, strategies, and crisis and these three areas form the main part of each organization that should be regarded as a set by the manager of any organization (Tichy \& Bennis, 2007:285-370). Basic functions of planning, organizing, leading and controlling require decision making. Managers at all levels of the organization decide to make new move, or solve the problem and put those decisions into action (Alagheh Band, 2006:23). Also, educational organizations deal with decision making in relation to many problems that extends to different levels of educational management. Educational systems have a special place among the various organizations that make decisions for their goals and tasks. In addition to the typical educational organizations that must make decisions about everyday things, educational organization should respond to the questions and needs of teachers, parents and the whole community (Mirkamaly, 2006: 172-170).

Today, pre-school education, more than any other time has gained necessity, importance and sensitivity. Working with children, teachers and parents at different levels of pre-school (care centers, daycare and kindergarten) needs precise and scientific supervision, monitoring, and management. Equipping managers and trainers with knowledge and new management approaches at this level is kind of investment for establishing correct relationship with manpower, children and families and taking advantage of the scientific and practical ideas will lead to positive performance at this level. About 12 million children under 6 years in the current situation, problems and issues related to child welfare, provisions of National plans and programs for young children and the change of educational system and comparable international collaborative projects, have dramatically reduced the attitude of "any which way manner and haphazardness" to a very significant extent. This is the situation in which the sensitive, constructive and defining role of managers and administrators of cultural and educational and preschool centers has become evident. Managers at this level should be able to take full advantage of researches and scientific findings for giving direction to their efforts in order to provide adequate and appropriate programs and making use of human relationships and partnerships with families and extensive knowledge about children and their needs. This is their directional, supportive, technical, collaborative and planning role that favorably forms their relationship with families and society and ensures next successful experiences of children (Mofidi, 2002, introduction and preface). In fact, the manager thinks as a planner and designer with thought and tries to build mutual understanding between the goals of the organization and the staff with consultation and continuous effort (Dobby, 2009). Since today, with things becoming complicated and rapid environmental changes and regarding the intellectual limitations that everybody is afflicted to, may be the only way to achieve to a logical, systematic, comprehensive and complete decision is through cooperation and collaboration with other organizations' staff (Mirsepasi, 2005:18).

Researches that have been carried out in this regard are as follows: Kazemi Kord Asiayee, in his research in 2005, in order to evaluate and identify the human skills of managers and its relationship with gaining the participation of students' parents in the affairs of secondary schools and high schools of the city of Babolsar, came to these results: 1 - There is a relationship between managers' human skills and gaining the participation of students' parents in the affairs of the school. 2- There is a relationship between the criterion of character recognition and respect for others by the manager and gaining the participation of students' parents in the affairs of the school. 3- There is no relationship between the ability to communicate with others by the manager and gaining the participation of students' parents in the affairs of the school. 4- There is a relationship between the criterion of understanding the needs and talents of others by the manager and gaining the participation of students' parents in the affairs of the school. 5- There is no relationship between the criterion of participating others in the decision making by the manager and gaining the participation of students' parents in the affairs of 
the school. 1 Daresh \& Playko (2007), in their study found that there is a meaningful relationship between social skill of managers and creating a positive and cooperative relationship and teachers' involvement in the planning of school affairs.

Also, in a research by Stronge (1999), it was suggested that managers' human skills are important either in schools or in business is the most important skill in gaining employees' participation in affairs such as finance, executive affairs, improving the environmental conditions and participation in the activities of the organization. Schneider (2006), in another study, concluded that social and communicational relationships mean establishing intimate relations with employees and having women cooperate and do teamwork in the direction of organization's goals are among essential characteristics for successful work of employers.

Jacobi (2006), in his research, indicated that there is a direct relationship between the level of participation of teachers in decision-making and managers' skills and competencies. He introduces the skill of establishing dynamic social relationships as necessary issues for participating teachers in decision-making. In another study, Marks \& Printy (2007) found that there is a significant relationship between managers' human and communicational skill and teachers' performance in teaching procedure and making evolution in teaching methodology and instruction.

Therefore, according to the findings of the research it was revealed that no study has been carried out in the domain of preschool centers and with regard to this research gap, researchers are trying to answer this basic question that whether human skills of preschool managers have an influence on the level of trainers' participation in taking educational measures and decisions in preschool centers (care centers, daycare and kindergarten); so that with inspiring from the obtained results in the instruction process take the best use of these results and work as guideline for educational authorities in the process of education in preschool centers.

\section{Methodology}

The present study is considered applied from the objective point of view and is considered descriptive with survey design from data collection point of view. Applied research is a research that is designed to solve a certain scientific or social problem or dilemma. Applied research should be used in a workshop or a factory or the community with a clear and defined manner. Descriptive study, from this viewpoint, describes the things that exist. This type of research includes describing, recording and analyzing the current situation. In this type of research there s an attempt to uncover the relationships among intact factors (variables). (Sarmad \& Bazargan, 2011)

The population of this study includes all preschool centers (daycares) of Isfahan in 2013, and sampling method in this study is a multi-stage sampling. So that, Isfahan has six education districts and two districts were randomly selected which are districts 3 and 5 in which 100 daycare centers are active. There are 64 centers in district 3 and 36 centers in district 5. There are 320 trainers in district 3 and 180 trainers in district 5 . 177 from district 3 and 123 from district 5 were selected through Morgan table with a total of 300.

To evaluate the level of trainers' participation in taking educational measures and decisions in preschool centers (care centers, daycare and kindergarten) of Isfahan a questionnaire including 30 five-item questions on Likert scale (very high, high, moderate, low, very low.) was used.

Aspects of participation in taking decision are: participation in planning and goal setting, active participation in group activities and decisions and believing in participation, offering solutions and suggestions or in other words resolving difficulties, making changes or improving affairs.

To evaluate preschool managers' human skills (daycare) a questionnaire including 15 questions with five items on Likert scale (very high, high, moderate, low, very low.) was used.

Thus, in the present study, the reliability of the questionnaire measuring human skills of directors was calculated as 0.90 through Cronbach's Alpha and the reliability of the questionnaire measuring the level of trainers' participation was calculated as 0.88 through Cronbach's Alpha.

\section{Results:}

Table 1: Sample descriptive indicators

\begin{tabular}{|l|l|l|l|l|l|}
\hline Variables & $\mathbf{N}$ & $\mathbf{M e a n}$ & $\begin{array}{l}\text { Max } \\
\text { Score }\end{array}$ & $\begin{array}{l}\text { Min } \\
\text { Score }\end{array}$ & $\begin{array}{l}\text { St. } \\
\text { Deviation }\end{array}$ \\
\hline Human skill & 300 & 2.9927 & 3.73 & 1.60 & 0.58531 \\
\hline participation in planning and goal setting & 300 & 2.0900 & 4.50 & 1.25 & 0.53144 \\
\hline $\begin{array}{l}\text { active participation in group activities and decisions and } \\
\text { believing in participation }\end{array}$ & 300 & 3.3558 & 4.33 & 1.92 & 0.66818 \\
\hline $\begin{array}{l}\text { offering solutions and suggestions or in other words resolving } \\
\text { difficulties }\end{array}$ & 295 & 2.0665 & 3.38 & 1.38 & 0.34867 \\
\hline Making changes or improving affairs. & 299 & 3.2196 & 4.50 & 1.33 & 0.85448 \\
\hline
\end{tabular}




\begin{tabular}{|l|l|l|l|l|l|}
\hline & & & & & \\
\hline Total Participation & 294 & 2.8137 & 3.57 & 1.80 & 0.51818 \\
\hline
\end{tabular}

Sample descriptive indicators for five variables understudy have been presented in table 1 along with sample volume.

The following results obtained using descriptive statistics:

Question a: is there a significant relationship between manager's human skills and the level of trainers' participation in four-dimensional aspects?

Table 2: Pearson correlation coefficient about the effect of managers' human skills on the level of trainers' participation

\begin{tabular}{||l|r|r|l|l|l|l|l|}
\hline \multicolumn{2}{|c|}{ COMPONEXYS } & $\begin{array}{l}\text { participation } \\
\text { planning } \\
\text { goal setting }\end{array}$ and \\
TEST
\end{tabular}

Answer to question a: Because the calculated correlation coefficient is larger than critical correlation coefficient of the table at $1 \%$ error level then it is concluded that there is a meaningful relationship between managers' human skill and the level of trainers' participation in taking educational measures and decisions in these aspects: (participation in planning and goal setting, active participation in group activities and decisions and believing in participation, offering solutions and suggestions or in other words resolving difficulties, making changes or improving affairs.)

Question b: how much is the semipartial correlation of human skills and level o participation?

Table 3: semipartial correlation of human skills

\begin{tabular}{|c|c|c|c|c|c|}
\hline $\begin{array}{r}\text { Variables } \\
\text { Statistic } \\
\text { Indicators }\end{array}$ & $\begin{array}{lr}\text { standardized partial } \\
\text { regression coefficient }\end{array}$ & $\begin{array}{l}\text { semipartial } \\
\text { correlation }\end{array}$ & $\begin{array}{r}\text { Minimum } \\
\text { Level }\end{array}$ & $\mathbf{T}$ & $\begin{array}{r}\text { Significance } \\
\text { Level }\end{array}$ \\
\hline Human skill & 0.38 & 0.48 & 0.33 & 9.32 & 0.000 \\
\hline
\end{tabular}

Answer to question b: according to the table the variable of "managers' human skill" with semipartial correlation of 0.48 shows a high correlation with participation in taking educational measures and decisions. Thus it enters the regression equation.

Question c: can human skill explain variable variance of participation in taking measures?

Table 4: Indexes and Statistics of Regression Analysis about the effect of human skills on the level of participation

\begin{tabular}{|l|r|r|r|}
\hline $\begin{array}{l}\text { Multivariate correlation } \\
\text { coefficient (R) }\end{array}$ & $\begin{array}{r}\text { R-Squared or Coefficient of } \\
\text { Determination }\end{array}$ & $\begin{array}{r}\text { adjusted } \\
\text { correlation coefficient }\end{array}$ & $\begin{array}{r}\text { Standard } \\
\text { Error }\end{array}$ \\
\hline 0.91 & 0.83 & 0.83 & 0.213 \\
\hline
\end{tabular}

Answer to question c: by entering human skill variable which has a high correlation with participation in taking educational measures and decisions, Explained variance of $83 \%$ is achieved. In other words, human skill can explain $83 \%$ of variance of participation in taking educational measures and decisions.

Question d: are managers' human skills significant in explaining the level of trainers' participation? 
Table 5: ANOVA for Regression

\begin{tabular}{|c|c|c|c|c|c|c|}
\hline $\begin{array}{r}\text { Source of } \\
\text { variation } \\
\text { V }\end{array}$ & $\begin{array}{r}\text { Degree of freedom } \\
\text { (D.F) }\end{array}$ & $\begin{array}{r}\text { Sum of squares } \\
\text { ( S.S ) }\end{array}$ & mean & $\begin{array}{l}\text { square } \\
\text { ( M.S ) }\end{array}$ & $\mathbf{F}$ & $\begin{array}{r}\text { Significa } \\
\text { nce level }\end{array}$ \\
\hline $\begin{array}{r}\text { Regression } \\
\text { effect }\end{array}$ & 2 & 65.35 & 32.67 & & 719.43 & 0.000 \\
\hline Residual & 290 & 13.17 & $\overline{0.045}$ & & & \\
\hline Total & 292 & 78.52 & & & & \\
\hline
\end{tabular}

Answer to question d: according to the data about ANOVA regression, it is concluded that: managers' human skills is significant in explaining the level of trainers' participation in taking educational measures and decisions. Thus the table says that: there is a meaningful relationship between managers' human skills and the level of trainers' participation in taking educational measures and decisions. The relationship is positive and direct.

Question e: can managers' human skills define the level of trainers' participation in taking educational measures?

Table 6: the variable entered in Regression equation

\begin{tabular}{|r|r|r|r|r|r|}
\hline $\begin{array}{c}\text { Variables } \\
\text { Statistic } \\
\text { Indicators }\end{array}$ & $\begin{array}{c}\text { Regression } \\
\text { Coefficient } \\
(\mathbf{B})\end{array}$ & $\begin{array}{c}\text { Standard } \\
\text { Error } \\
\text { SE. B }\end{array}$ & $\begin{array}{c}\text { Standard } \\
\text { Coefficient }\end{array}$ & \multicolumn{1}{|c|}{ S } & $\begin{array}{c}\text { Significance } \\
\text { Level }\end{array}$ \\
\hline Human skill & $\mathbf{0 . 4 8}$ & $\mathbf{0 . 0 5 2}$ & $\mathbf{0 . 3 8}$ & $\mathbf{9 . 3 2}$ & $\mathbf{0 . 0 0 0}$ \\
\hline Constant & $-\mathbf{0 . 6 3}$ & $\mathbf{0 . 0 9 3}$ & & $-\mathbf{- 6 . 8 3}$ & $\mathbf{0 . 0 0 0}$ \\
\hline
\end{tabular}

Answer to question e: according to the table we can say: managers' human skills are influential in the level of trainers' participation in taking educational measures and decisions.

Based on the scores of managers' human skills we can predict the score for trainers' participation in taking educational measures and decisions.

The regression equation of this study is as follows:

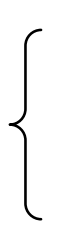

Examining research question

Whether human skills of preschool managers have an influence on the level of trainers' participation in taking educational measures and decisions in preschool centers (care centers, daycare and kindergarten)?

According to table 2 we conclude that: there is a significant relationship between manager's human skills and the level of trainers' participation in four-dimensional aspects.

According to table 4, 5, 6 we concluded that: manager's human skills have an influence on the level of trainers' participation in taking educational measures and decisions and we can predict the score for trainers' participation in taking educational measures and decisions based on the scores of managers' human skill.

The comparison of the findings of this study with other studies:

The results of the study of Kazemi Kord Asiyayee (2003) indicated that: there is a meaningful relationship between managers' human skills and parent participation in school affairs. The results of this study are in line with the findings of the present study. 
The results of the study by Daresh \& Playko (2007), suggest that there is a meaningful relationship between social skill of managers and creating a positive and cooperative relationship and teachers' involvement in the planning of school affairs. And these results are in accordance with the findings of the present study.

The results of Stronge's research (1999) indicate that managers' human skills are important either in schools or in business is the most important skill in gaining employees' participation in affairs such as finance, executive affairs, improving the environmental conditions and participation in the activities of the organization. And these results are in line with the findings of the present study.

The results of the study by Schneider (2006) suggest that social and communicational relationships mean establishing intimate relations with employees and having women cooperate and do teamwork in the direction of organization's goals are among essential characteristics for successful work of employers. And these results are in line with the findings of the present study.

The results of the study by Jacobi (2006) indicate that there is a direct relationship between the level of participation of teachers in decision-making and managers' skills and competencies. He introduces the skill of establishing dynamic social relationships as necessary issues for participating teachers in decision-making. And these results are in line with the findings of the present study.

And finally, the results of the study by Marks \& Printy (2007) denote that there is a significant relationship between managers' human and communicational skill and teachers' performance in teaching procedure and making evolution in teaching methodology and instruction. And these results are in line with the findings of the present study.

\section{Conclusion}

According to what is mentioned, we can conclude that: the findings of the present study are in line with those of Kazemi Kord Asiyayee (2003), Daresh \& Playko (2007), Stronge (1999), Schneider (2006), Jacobi (2006) and Marks \& Printy (2007).

According to the ideas of Alaghe band (1994), Shirazi (1995), Daresh \& Kontz (1994), and Mofidi (2002), in general managers' human skill will lead to creating an environment of understanding and cooperation, right judgments and a sense of security and freedom of expression among employees and Coordination among activities.

This study tried analyze the role of managers' human skills on the level of trainers' participation in taking educational measures and decisions in preschool centers of Isfahan, considering theoretical foundations of the three skills of Katz and Hauser's employee participation (Tousi). This study found the following results based on its findings: there is a meaningful relationship between managers' human skills and each component of trainers' participation. Also there is a high correlation (0.78) between managers' human skills and each component of trainers' participation and the relationship is positive and direct, in other words, the higher is human skills of the directors of preschool centers, the higher will be the level of trainers' participation in each aspect of four-dimensional participation. And regarding the average level of human skills of the directors of preschool center, this is dramatically influential on the level of trainers' participation in taking educational measures and decisions.

Therefore, the average level of managers' human skill can improve trainers' participation in two components of participation in "planning and goal setting" and "offering solutions and suggestions or in other words resolving difficulties". We can predict the score for trainers' participation in taking educational measures and decisions based on the scores of managers' human skill.

Based on what is mentioned it can be concluded that managers who are working in daycare centers and kindergartens of Isfahan's 2, 3 and 5 districts do not have high human skills. This has lead to low participation of trainers in two aspects of participation.

Manager's needs assessment is a serious necessity in Education and Welfare organizations that necessitates the design of standardized forms to monitor and evaluate of managers' skills through the process of continuous assessment, in order to identify strengths and weaknesses of Managers' existing skills. Regarding the fact that preschool includes children between 3 and 6 , and since these ages are considered crucial in human education, those who are responsible for the management and training of children in this age period are very important. Thus employing those who have the competence and eligibility in managing and mentoring people in this period is very essential and should be placed at the top of the objectives of Education and Welfare organizations.

Also, given that human skill of managers of preschool centers is not high, thus continuous training of these skills to managers should be a top business of authorities who are responsible for the issue.

Holding workshops and training courses for managers by the Education and Welfare organizations can help create balanced management skills. And since daycare centers and kindergartens are under supervision of two different organizations that are Education and Welfare organizations and each one follows his own goals, 
cooperation and establishing relations between the two organizations and creating common and higher goals for them will lead to the growth and success of these organizations.

To improve the level of human skills of the managers of preschool centers of Isfahan, the use of printed materials or holding workshops and training courses is recommended. Also, by holding training courses for newly employed managers, desirable influences can be achieved through the following forms:

- To hold in-service training classes with needs analysis and defining materials and contents that suits their needs.

- To hold group meetings and group and intergroup training for conveying managers' practical and scientific skills to another.

Since having high level of human skill is necessary for managers because they deal with children, the recruitment of trainers and managers of these centers should be revised and more precise and principled criteria for identifying the skills of these people should be implemented. It is quite decent that Education and Welfare organizations value the preschool period more and overcome the shortcomings by a more precise supervision on the performance of the managers of these centers.

\section{References}

[1] Ostadzadh, Maryam. (2009). Factors that reduce or increase the productivity of human resources. Online Journal of Management Strategy

[2] Bazallhy, Muhammad. (2003). Management of pre-school centers, Tehran: Publication of Khorramshahr

[3] Parkinson, North Kut, and others. (1992). Great ideas in management, translation of M. Iran Nezhad Parizi, Tehran: Iran Banking Institute Press.

[4] Paul Hersey \& Kenneth Blanchard (1995), Human Resource Management, translated by Ali Alagheh Band, Tehran: Amir Kabir Publication.

[5] Dobby, Vicki. Saidi, R., (2009). Public Relations Management, Online Journal of management solution

[6] Zomorodian, A. (2008), change management, fifth edition, Tehran: Publication of Industrial Management Organization

[7] Sarmad, Z., and Bazargan, A. (2011). Research Methods in Behavioural Sciences, Tehran: Agah Publications.

[8] Shirazi, A. (1995). Tehran, Publications of Jahad Daneshgahi of Mashhad University

[9] Toosi, MA (2006). Participation in management and ownership, Tehran: Center for Public Management.

[10] Alagheh Band, A. (1994). Preparations for Learning Management, Tehran, Beast Press.

[11] Alagheh Band, A. (2006). Theoretical Foundations and Principles of Educational Management, Tehran. Ravan Publication

[12] Fardi Azar, A. (2002), the comparison of TOPSIS and AHP models to measure managers' skills, MA Thesis, Tehran University

[13] Kazemi Kord Asiayee, Mitra. (2003). The relation between managers' human skills and gaining the participation of students' parents in the affairs of secondary schools and high schools of the city of Babolsar, MA thesis, University of Al-Zahra

[14] Katz, Robert L. (2001), Skills of a successful manager, Translator: Mahmoud Tootoonchiyan, Public Administration Training center press.

[15] Mofidi, F, (2002). Management of pre-school centers, Tehran, Allameh Tabatabaei University Press.

[16] Mirsepasi , N. (2005). The role of Staff in managers' decisions, Journal of Public Management, No. 2.

[17] Mirkamaly, Mohammad. (2006). Educational leadership and management, Tehran Yastoroon

[18] Daresh, John C \& Playko, Marsha A , (2007), Aspiring and Practicing of Critical Skills for Beginner Leaders and It's Relation With Teachers Performance, Journal of Educational Administration, Vol 32, No 3 . ( University of Northern Colorado, Greeley, Colorado, USA \& Hazelwood Elementary School , Netwark, Ohio, USA )

[19] Jacobi, Pedro (2006), Participation in Decision Making by Teachers, Center for Scholars Washington, D.C .

[20] Marks, Helen M \& Printy, Susan M, (2007), Principle Leadership and School Performance : An Integration of Transformational and Instructional Leadership, Educational Administration Quarterly, Vol 39, No 3.

[21] Rice, Ellen Marie \& Schneider, Gail , (1994), A Decade of Teacher Empowerment : An Empirical Analysis of Teacher Involvement in Decision Making, Journal of Educational Administration, Vol 32 , No 1.

[22] Schneider, Beth, (2006), For entrepreneurs Who Hate to Give up Control .These Five Tips Will Help You Relax and Learn to Let Others Help Out, Blackwell Pub. , Centre for Sustainable Community Development, Simon Fraser University -Harbour Centre , Vancouver, British Columbia, Canada .

[23] Stronge , James H , (1999), Relation Between Leadership Skills in School and Business, and Employees Participation , Journal of Human Relation, Vol 45 , No 11 . (School Administrator)

[24] Tichy, Noel . M, Bennis, Warren. G,(2008), Gudgment:How winning leadersmake grate calls, Piguin group Pub, (us). 